\title{
Література
}

1. Астапов В. М. Введенне в дефектологию с основами нейропатопсихологии / В. М. Астапов. - $\quad$ М. : Международная педагогическая академия, 1994. 2. Забрамная С. Д. Из истории методов выявления умственной отсталости / С. Д. Забрамная. - М. : Просвещение, 1970. - 236 с. 3. Забрамная С. Д. Материалы психолого-педагогического обследования в медико-педагогических комиссиях / С. Д. Забрамная. - М. : Просвещение, 1985. - 218 с. 4. Забрамная С. Д. Отбор умственно отсталых детей в специальные учреждения / С. Д. Забрамная. - М. : Просвещение, 1988. - 113 с. 5. Забрамная С. Д. Указания к работе над курсом «Методы отбора детей во вспомагательную школу»/ С. Д. Забрамная. - М. : Просвещение, 1970. - 78 с. 6. Карімова Р. Б. Науково-методичні основи діагностики й корекції психоневрологічного розвитку дітей дошкільного віку з церебральноорганічною патологією / Р. Б. Карімова / автореф. дис. на здобуття наукового ступеня д-ра психол. наук: Інститут спеціальної педагогіки АПН України. - К., 2002. - 20 с. 7. Липа В. А. Основи корекційної педагогіки / В. А. Липа. - Д. : Лебідь, 2002. - 315 с. 8. Синьов В. М. Специфічні закономірності розвитку психіки у дитини. Діти 3 обмеженими фізичними та розумовими можливостя ми в системі корекційного навчання i виховання / В. М. Синьов. - К. : Вища школа, 1997. - 325 с. 9. Стадненко Н. М. Значение психологического обследования в работе отборочных медико-педагогических комиссии / Н. М. Стадниченко // Дефектология. - 1990. № 2. 10. Стадненко Н. М. Очерки по психологии умственно от сталого ребенка. К. : Рад. шк., 1967. - 128 с. 11. Стадненко Н.М. Проблеми работи медикопедагогических комиссии / Н. М. Стадненко // Дефектология. - 1989. - № 6. 12. Стадненко Н. М. Роль диференціальної діагностики розумо вого розвитку дітей під час розробки стандартів освіти / Н.М. Стадненко // Дефектологія. 2001. - № 3. 13. Стадненко Н. М. Діагностика відхилень в розумовому розвитку учнів. - К. : Освіта, $1993 . \quad$ - 239 с. 14. Шипицына Л. М. Нейропсихологические аспекти диагностики детей в процессе коррекционноразвивиющего обучения / Л. М. Шипицына // Дефектология. - 1995. - № 5. - С. 78-92.

УДК: 159.9:504

Дарія Федоренко

\section{ОСОБЛИВОСТІ ПРОВЕДЕННЯ ФОРМУВАЛЬНОГО ЕКСПЕРИМЕНТУ З ПРОБЛЕМИ ВИХОВАННЯ ЕКОЛОГІЧНОЇ КУЛЬТУРИ СТАРШОКЛАСНИКІВ}

Федоренко Д. О. Особливості проведення формувального експерименту 3 проблеми виховання екологічної культури старшокласників.

У статті представлено результати формувального експерименту 3 проблеми виховання екологічної культури старшокласників. Автор додержується думки про те, що для проведення формувального експерименту зі старшокласниками у загальноосвітній школі необхідним $є$ забезпечення набуття поглибленого рівня екологічної освіти відповідно до спеціалізації, усвідомлення взаємозалежності екології й економіки, знання груп професій за їх впливом на навколишній світ, особливості впливу майбутньої професії на довкілля. У статті розкрито ефективні форми i методи виховання екологічної культури старшокласників - екологопсихологічні тренінги та проблемні методи.

Ключові слова: екологічна культура, учні старшого шкільного віку. 
Федоренко Д. А. Особенности проведения формирующего эксперимента по проблеме воспитания экологической культуры старшеклассников.

В статье представлены результаты формирующего эксперимента по проблеме воспитания экологической культуры старшеклассников. Автор придерживается мнения о том, что для проведения формирующего эксперимента со старшеклассниками в общеобразовательной школе необходимо обеспечение приобретения углубленного уровня экологического образования в соответствии со специализацией, осознание взаимозависимости экологии и экономики, знание групп профессий по их влиянию на окружающий мир, особенности воздействия будущей профессии на окружающую среду. В статье раскрыты эффективные формы и методы воспитания экологической культуры старшеклассников - эколого-психологические тренинги и проблемные методы.

Ключевые слова: экологическая культура, учащиеся старшего школьного возраста.

Fedorenko D. A Features of forming experiment on the problem of ecological culture education high school students.

The article presents the results of a formative experiment on the problem of education of ecological culture of senior pupils. The author is of the opinion that for the formative experiment with high schoolchildren in a school is necessary to ensure the acquisition of indepth level of environmental education according to specialization, the awareness of the interdependence of ecology and economy, knowledge of occupational groups by their influence on the world, especially the impact of future trade environmental environment. The article deals with effective forms and methods of education of ecological culture of senior pupils - ecological and psychological training, problematic methods.

Keywords: ecological culture, high schoolchildren.

Початок XXI століття характеризується тим, що суспільство усвідомило цінність гармонійного життя у природі, що цілком $є$ залежним у майбутньому від рівня вихованості екологічної культури підростаючого покоління. Ефективність будь-яких виховних справ, що використовуються у процесі розвитку особистості, визначається через iї поведінку, екологічно доцільну діяльність. Ставлення підростаючого покоління до природного оточення характеризується через їхню екологічну грамотність, екологічну свідомість та естетичні почуття, що виникають під час природоохоронної роботи, через контакти із природою. Нині в системі виховання екологічної культури народжуються принципово нові явища, суперечливими $є$ і нові тенденції, які не мають аналогів у минулому. Нові завдання, що ставляться перед учнями старшої школи, стосуються сфери екологічної культури, закріплені у Концепції екологічної освіти України. Зокрема, у Концепції наголошено, що в загальноосвітньому навчальному закладі третього ступеню має бути забезпечено набуття старшокласниками поглибленого рівня екологічної освіти відповідно до спеціалізації. При цьому учні старших класів мають усвідомити взаємозалежність екології й економіки, знати групи професій за їх впливом на навколишній світ, особливості впливу на довкілля професії, яку вони обирають. Також старшокласники мають бути обізнаними 3 екологічним законодавством відповідної галузі господарства, добре орієнтуватись в екологічних проблемах, з якими стикається українське суспільство [3].

Цінний досвід досліджень щодо проблеми виховання екологічної культури накопичено останніми роками в дисертаційних дослідженнях. Окремі аспекти розкрито в дисертаціях таких авторів, як І. Глухов «Формування еколого-правової компетентності майбутнього вчителя у процесі валеологічної підготовки» [1]; Є. Копилець «Виховання екологічних ціннісних орієнтацій підлітків у процесі 
вивчення загальної географії» [2]; К. Магрламова «Виховання в учнів ціннісного ставлення до природи як складової природоохоронної роботи в основній школі» [4]; I. Трохимчук «Формування екологічної вихованості учнів основної школи у процесі дослідницької діяльності з екології у загальноосвітніх навчальних закладах» [6], у монографії С. Романа [5] та ін., але проблема виховання екологічної культури старшокласників у навчально-виховному процесі ще не набула повного розкриття.

Метою статmі $є$ розкриття дієвих форм, методів, аналіз результатів експериментального дослідження щодо виховання екологічної культури учнів старшої школи.

Під час формування екологічної культури старшокласників важливе значення має вибір ефективних форм i методів виховної робот. Під час проведення формувального експерименту широко застосовувалися проблемні методи (обговорення, диспут, конференція, рішення навчальних завдань), що передбачало постановку емоційно значущих для учнів старшої школи запитань, що вимагають активного пошуку рішень у процесі спілкування. Найпродуктивнішим проблемним методом щодо виховання екологічної культури був диспут, під час якого ми виявляли розбіжності в поглядах учнів на різні екологічні проблеми, виникала можливість перетворити їх на предмет детального аналізу тощо. Важливо, що диспут надавав можливість старшокласникам досліджувати проблемні ситуації та досягати поставленого результату. Діяльність старшокласників як певної спільноти дослідників проблеми виховання екологічної культури організовувалась за такими стадіями:

1. Подання емоційного тексту, що розкриває певну екологічну проблему у формі опису регіональної ситуації.

2. Визначення «оппонентів», організація діалогічної комунікації, у процесі якої відбувалася інтерпретація емоційного тексту з різних позицій.

3. Забезпечення конфронтації через розкриття смислових позицій старшокласників. Унаслідок того, що ця стадія грунтується на принципі діалогічності й соціально опосередкованою, суперечності між прихильниками протилежних поглядів розв'язувалися через перехід на вищий рівень екологічних знань та екологічного мислення. Завдяки цьому учасники диспуту переходили 3 індивідуального рівня аналізу екологічних проблем регіону на системний.

4. Реконструкція міжособистісних стосунків на груповому та індивідуальному рівнях. На цій стадії у старшокласників виникали нові перспективи для здійснення екологічно виправданої поведінки, формувалися нові підходи до оцінки власного внеску у природоохоронну роботу.

Виховний потенціал диспуту в умовах перетворення групи учнів на спільноту дослідників забезпечувався тим, що старшокласники отримували можливість висловлювати різні ідеї щодо регіональної екологічної ситуації, уточнювати власне розуміння змісту екологічних понять, оцінювати наслідки різних навичок ведення екологічно доцільного способу життя i, загалом, спільно мислити, відчуваючи задоволення від інтелектуального пошуку та діалогічного спілкування. Завдяки цьому в учнів підвищувався рівень екологічної культури, адже вони вчилися критично мислити, збирати інформаційні матеріали про довкілля, зважувати альтернативні думки, приймати рішення на основі моделей екологічно доцільної поведінки. Під час формувального експерименту широко використовувалися такі прийоми, як «мозковий штурм», «дерево рішень», «дебати», що були спрямовані на покращання інтерактивної взаємодії. Емоційні тексти, що розкривали певну екологічну проблему у формі опису регіональної ситуації добиралися таким чином, щоб вони були значущими для старшокласників і викликали різні погляди, думки. Отже, проблемні 
методи у вихованні екологічної культури старшокласників не лише активізували пізнавальну діяльність, але і сприяли поглибленому аналізу екологічних проблем, стимулювали пошук організації екологічно доцільної діяльності.

Експериментальні дані підтверджують, що для виховання екологічної культури не менш важливим є метод проведення літературних вечорів вшанування природи, оскільки у цей період старшокласники сприймають природу на естетичному рівні, оскільки літературний вечір має розпочинатися 3 підготовки рекламних заходів оформлення яскравих, естетично оформлених запрошень, оголошення конкурсу на кращу афішу. Кожний літературний вечір вшанування природи $\epsilon$ неповторним, оскільки змінюються умови його проведення, змінюється склад виконавців, удосконалюється сценарій тощо. Рефлексивний компонент забезпечується за допомогою проведення анкетування, записів у відгуках у соціальних мережах Інтернет, організації виставки творчих робіт тощо.

Важливо, що старшокласники діляться власними враженнями, складають короткі відгуки, аналізують прорахунки та цікаві ідеї, розкривають емоції. Ми також вважаємо, що для аналізу результативності проведення літературного вечора вшанування природи можна запропонувати анкетування і учасників, і глядачів. Доцільними, на наш погляд, $є$ такі запитання:

1. Що саме сподобалося Вам на літературному вечорі вшанування природи?

2. Які почуття та думки викликали виступи учасників?

3. Що нового Ви дізналися про ставлення письменника до природи? Чи розширив літературний вечір ваші знання про красу природи?

4. Чи допоміг Вам вечір зрозуміти власне ставлення до природи?

5. Які вислови учасників вечора про природу, на Ваш погляд, були найвлучнішими?

Важливо, щоб оцінка літературного вечора вшанування природи була щирою і чесною, оскільки творчість письменників або поетів не має залишати старшокласників байдужими. Так, старшокласники, які входили до експериментальної групи, написали такі відгуки про проведення літературного вечора: «Цей вечір викликав різні емоції та розкрив ті проблеми, що має людина у відносинах із природою, за яких ми навіть й не здогадувалися. Ми самі слухали і читали, малювали, готували рекламні проспекти. Цікаво, що вечір створювався всіма разом, нам допомагали не лише вчителі української мови та літератури, а й класні керівники, соціальний педагог і психолог. Це були дні, коли ми дійсно більш бережливо почали ставитися до природи, навчилися сприймати красу оточуючого довкілля».

Підкреслимо, що літературний вечір вшанування природи постав для учасників експериментальної групи джерелом для написання творів-роздумів, а у тому разі, коли учні старшої школи запрошують і молодших школярів, учнів основної школи, літературні вечори сприяють створенню виховних традицій у шкільному колективі. Отже, під час таких вечорів потрібно долучати учнів до вивчення у джерелах поетичної творчості, красного письменства задля підвищення рівня естетичного сприйняття природи, розширеннякультурного світогляду тощо.

Особливими у ході формувального експерименту були розроблені нами нові форми позанавчальної виховної роботи, а саме «Індивідуальна творча справа екологічно доцільне споживання води», конкурси «Здоров’я планети - здоров'я людини», дебати «Промисловцям легше живеться, ніж аграріям», година милування природою, еко-служба школи. А також методи: індивідуально-комунікативні, практичні вправи, пояснювально-ілюстративні, соціально-діяльнісні, діагностувальне обстеження, анкетування й корекція пасивної екологічної поведінки тощо. 
У змісті формувального експерименту учні розробляли такі питання: «Характеристика споживацького ставлення до природи», «Природоохоронна робота школи», «Взаємодія людини із природою», «Екологічна компетентність», «Екологічна культура як матеріальна і духовна цінність», «Екологічна етика і естетика». Під час завдань нами було використано такі методи, як діалогічне спілкування, оцінка природних явищ 3 позицій людини, яка має високий рівень екологічної свідомості. Дієвими та цікавими для старшокласників виявилися еколого-психологічні тренінги «Формування позитивної мотивації до застосування екологічних знань у побуті», «Оцінка впливу моєї майбутньої професії на природу». Розроблені та проведені нами тренінги передбачали підготовчий етап, етапи діалогічного спілкування, етап рефлексії та зворотний зв'язок. Старшокласники працювали у парах та в групах, оволодівали діалогічними способами спілкування, відстоювали інтереси різних груп населення, спеціалістів різних галузей народного господарства тощо.

Конкретні екологічні справи, які були проведені учнями експериментальних груп, такі: аналіз екопроблем міста, регіону, підготовка творчих проектів із використанням шкільних підручників і додаткової літератури, планування організації допомоги у природоохоронній роботі (вересень); виступи на екологічних акціях, участь у проведенні екологічних казок для учнів молодшого віку (жовтень); формування творчих груп «промисловців», «аграріїв», «транспортників», «екотуристів», «лікарів», «екологів» тощо, підготовка диспутів та конференцій 3 екологічної проблематики «Збережемо тепло у домівках» (січень); ознайомлення із традиціями європейських країн щодо збереження природи та моделей екологічно доцільної поведінки (Німеччина, Франція, Чехія, Польща та ін.), обговорення питань щодо підготовки та проведення «Літературних вечорів вшанування природи рідного краю» (лютий); ознайомлення із традиціями ціннісного ставлення українського народу до природи, організація й участь у проведенні Всеукраїнської екологічної акції 3 охорони квітів-первоцвітів «Первоцвіт», створення стіннівок до Всесвітнього дня котів (1 березня), Дня Землі (20 березня), участь у проведенні Всесвітньої акції «Година Землі» (31 березня); проведення тематичної лекції у день екологічних знань (15 квітня), організація соціально-екологічних практикумів у дні захисту навколишнього середовища від екологічної небезпеки (15 квітня), участь у щорічній міжнародній екологічній акції на підтримку заповідної справи - «Марш парків» (3-4 тиждень квітня), вшанування пам'яті загиблих у радіаційних аваріях і катастрофах (26 квітня) у Роковини Чорнобильської катастрофи (квітень).

Проведений формувальний експеримент підтвердив ефективність розробленої на основі обгрунтованих педагогічних умов методики формування екологічної культури старшокласників (організаційні, пов'язані з розгортанням екологізації культурноосвітнього простору у системі роботи школи; змістово-процесуальні, детерміновані трансформацією національних екофільних традицій i поступовим переходом до сучасних європейських стандартів; особистісно-розвивальні, спрямовані на самореалізацію i саморозвиток старшокласника, виховання його в дусі загальносвітових культурних традицій, з урахуванням вимог екологічної етики). В учнів старшої школи, які входили до експериментальної групи, відбулися статистично достовірні кількісні та якісні зміни, що виявилися в позитивній динаміці рівнів вихованості екологічної культури (див. рис. 1). Зокрема, зменшилась кількість учнів низьким рівнем екологічної культури, натомість зросла кількість учнів із середнім рівнем. Позитивна динаміка спостерігається також у зміні кількості старшокласників iз достатнім рівнем екологічної культури, певні зрушення були і у показниках, що засвідчили зростання високого рівня екологічної культури в учнів. 


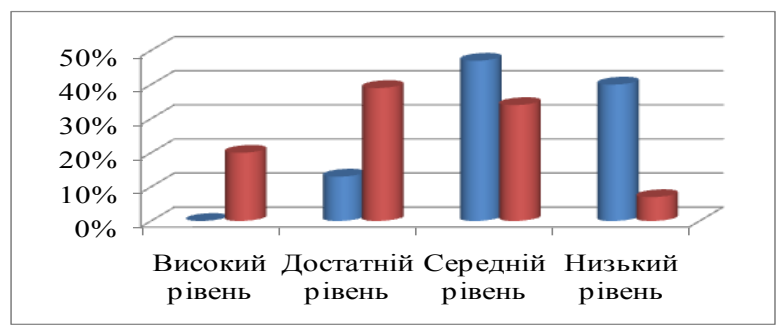

Рис. 1. Динаміка рівнів вихованості екологічної культури старшокласників (дані експериментальної групи - констатувальний та формувальний експерименти)

Застосування непараметричного критерію Вілкоксона засвідчило, що зміни рівнів вихованості екологічної культури у старшокласників експериментальних груп мають статистично достовірний характер $(\alpha=0,05)$. У контрольних групах за час проведення формувального експерименту теж мали місце певні зрушення, проте вони не досягають рівня статистичної значущості.

Отримані результати надають підстави зробити висновок, що реалізація ефективних форм, методів через визначені педагогічні умови стимулюють розвиток екологічного мислення учнів старшої школи, сприяють більш глибокому розумінню сутності екологічних понять, засвоєнню екологічних знань, а також формуванню емоційно-ціннісного ставлення до оточення, зміні способу життя з прагматичного на екологічно доцільне. Перспективою дослідження є розкриття ефективності процесу екологізації освіти, від якої залежать чинники виховання екологічної культури учнів.

\section{Література}

1. Глухов I. Г. Формування еколого-правової компетентності майбутнього вчителя у процесі валеологічної підготовки : автореф. дис. на здобуття наукового ступеня канд. пед. наук: [ спец. 13.00.04 - теорія і методика професійної освіти ] / Іван Геннадійович Глухов .- Умань, 2013 .- 20 с. 2. Копилець С. В. Виховання екологічних ціннісних орієнтацій підлітків у процесі вивчення загальної географії: дис. ... канд. пед. наук : [спец. 13.00.07 - теорія і методика виховання] / Копилець Євгеній Вікторович. - Полтава, 2013. - 290, [11] с. 3. Концепція екологічної освіти України (Затверджено Рішенням Колегії МОН України № 13/6-19 від 20.12.01.). [Електронний ресурс]. - Режим доступу: http://shkola.ostriv.in.ua/publication/code148B3B2021C2C/list-B407A47B26 - Дата звернення: 07.03.2014. - Загл. $з$ екрану. 4. Магрламова К. Г. Виховання в учнів ціннісного ставлення до природи як складової природоохоронної роботи в основній школі: дис. ... канд. пед. наук : [спец. 13.00.07 - теорія і методика виховання] / Магрламова Камілла Газанфарівна. Дніпропетровськ, 2011. - 273, [9] с. 5. Роман С. В. Теоретико-методологічні основи формування еколого-гуманістичних цінностей у процесі шкільної хімічної освіти : [монографія] / С. В. Роман. - Луганськ : ЛНУ імені Тараса Шевченка, 2013. - 459 с. 6. Трохимчук I. М. Формування екологічної вихованості учнів основної школи у процесі дослідницької діяльності з екології у загальноосвітніх навчальних закладах: автореф. дис. на здобуття наукового ступеня канд. пед. наук : [спец. 13.00.07 - теорія і методика виховання] / Трохимчук Ірина Михайлівна. - Умань, 2014. - 20 с. 